\section{Insights into Classic Theatre Market Segments}

\author{
Mirna Leko Šimić \\ University of Josip Juraj Strossmayer, Faculty of Economics, Osijek, Croatia \\ lekom@efos.hr
}

\section{Ana Pap}

University of Josip Juraj Strossmayer, Faculty of Economics, Osijek, Croatia ana.pap.88@gmail.com

\begin{abstract}
Marketing segmentation is one of the key strategic elements in marketing planning that helps identifying key consumer groups and their characteristics and enables the adaptation of marketing strategies to different target consumers. The aim of this paper is paper aims to segment classic theatre audiences based on their attendance frequency and identify major socio-demographic characteristics of each segment. A self-completion questionnaire was developed upon analysis of previous studies and was distributed to the population in an area of about $50 \mathrm{~km}$ around Osijek. The research was conducted on a convenient sample, using an in-person method in two different intervals: in the first interval, research was conducted on young respondents (18-34), and in the second interval, research was conducted on adult respondents (age 35+). Altogether 1315 participants took part in the research. Statistical techniques of univariate analysis (frequency distribution and central tendency measures), ANOVA, and two-step cluster analysis were used.
\end{abstract}

The results of the study have identified six classic theatre segments: young theatre friends, young theatre acquaintances, young theatre strangers, adult theatre friends, adult theatre acquaintances, adult theatre strangers. Each segment is described in detail by their geographic (distance from the venue), demographic (age, income, marital status, education, employment) and psychographic characteristics (social activities, free time spending, and informing gathering about classic theatre offer) characteristics. The research results emphasized the differences in classic theatre audiences, which calls for continuous market segmentation in order to ensure timely recognition of consumer trends and changes in preferences. This would enable theatre management to adapt and implement adequate marketing initiatives and strategies.

Keywords: classic theatre, marketing segmentation, theatre audience

\section{Introduction}

Classic theatre is a social, situational, and experiential phenomenon rather than a fixed or tangible product (Walmasley, 2011) and therefore needs a special marketing approach toward customers. Marketing experts have agreed that market segmentation is one of the key strategic elements in marketing planning (Colbert,
ORIGINAL SCIENTIFIC PAPER

RECEIVED: JUNE 2020

REVISED: SEPTEMBER 2020

ACCEPTED: NOVEMBER 2020

DOI: 10.2478/ngoe-2020-0023

UDK: $339.138: 792$

JEL: M31, Z11

Citation: Leko Šimić, M., \& Pap, A. (2020). Insights into Classic Theatre Market Segments. Naše gospodarstvo/Our Economy, 66(4), 50-62. DOI: 10.2478/ngoe-2020-0023

\section{NG OE}

NAŠE GOSPODARSTVO OUR ECONOMY

$\frac{\text { Vol.66 No.4 } 2020}{\text { pp. } 50-62}$


1994; Kotler and Scheff, 1997; Conway and Whitelock, 2007) that helps identifying key consumer groups and their characteristics and enables adaptation of marketing strategy to different target consumers. In this way, market segmentation assists in structuring and focusing on an organisation's marketing management activities. In other words, such a study can help theatre management understand why people engage with theatre and contribute to building an efficient relationship with existing audiences as well as recognize the specific potential customer. This issue has been recognized earlier by Heilbrun and Gray (2001) and Reiss (1994), who emphasized the importance of identification of both theatre goers and non-goers. According to Reiss (1994), it can ease the reach to perspective audience cost efficiently and with the most persuasive message. When faced with restricted public theatre budgets, this would be of utmost importance. Botha and Slabbert (2011) stated that the segmentation of theatre audiences can be an effective tool to divide existing and potential markets into homogeneous groups based on meaningful characteristics that could be profitably targeted. Moreover, it may help forecasting to forecast future trends of theatre consumption (Grisolia et al., 2010). Therefore, the market segmentation strategy as we know it in business or conventional marketing can also be applied in non-profit marketing, in this case, the marketing of public cultural institutions.

This study seeks to extend the well-established academic background of market segmentation to the context of classic theatre in Croatia. Several studies have recognized the challenge of the aging loyal theatre audience (Peterson, et al., 2000; Taylor et al., 2001; Colb, 2001; Carson, 2004; Turrini et al., 2012, and among others) and called for building new strategies to recognize and attract younger audiences. In this context Buljubašić et al. (2020), for example, have identified the need for unconventional marketing based on social media to reach younger audiences and to attract them to Croatian classic theatres.

This study aims to identify key classic theatre market segments and their characteristics in order to provide key elements for creating efficient marketing strategies for the theatre analysed in the study. The segmentation criteria used in the paper are the age (young vs. adult, i.e. up to the age of 35 and over 35, respectively) and theatre attendance frequency. The reason for such an approach was that previous studies in Croatia have been done separately on young and adult audiences (Leko Šimić \& Pap, 2020), so it was found interesting to compare the two age-based segments; Secondly, the population of 35+ has already built its "cultural profile," and it is highly unlikely that it will change significantly, whereas young existing and potential audiences can be reached by adequate marketing strategies, and their attitudes and behavior are easier to change. Chytková, et al. (2012) also confirmed that age is a significant criterion to segment audiences. They found that older audiences (over 60) in the Czech Republic are the most frequent classic theatre attendees. The same situation exists in Croatia, and if this is related to the longterm trend of the decline of classic theatre audiences (Leko Šimić \& Pap, 2020), it is clear that a detailed age segments analysis is needed. Moreover, although several newer studies have concentrated on motivational factors (Walmsley, 2011; Obaidalahe \& Steils, 2018), engagement (Pap et al., 2017), satisfaction (Leko Šimić \& Pap, 2019) and other factors affecting theatre attendance, Hager and Kopczynski Winkler (2012) warned that neither scholars nor managers can afford to underemphasize the value of demographics in predicting performing arts attendance.

This paper is the first in Croatia that studies has studied the different classic theatre segments and to provide insight into youth and adult theatre consumers' profiles. The findings of the study may help theatre management in the creation of the best possible programs and marketing activities to retain existing and attract new audiences.

The paper is organized in the following way. In the introductory part, the emphasis is on the need for marketing orientation and use of marketing tools for classic theatre and its market survival, focusing on market segmentation. In the literature review section, a short overview of historic and recent studies that focus on theatre market segmentation and describe the methods and models used as well as their results in terms of identified market segments are provided. The third part of the paper is focused on our research with methodology, research results, and discussion. The last part, the conclusion, summarizes our findings and identifies limitations and areas for further research.

\section{Literature Overview}

Segmentation of performing arts audiences, as one of the most fundamental techniques of targeted marketing, has been widely discussed in the literature (e.g. Kotler \& Scheff, 1997; Berstein, 2007).

Most of the existing research on cultural organizations' marketing identifies key segmentation criteria as demographic (age, gender, income), geographic (region, urban/ rural, distance from the venue), and psychographic (lifestyle, personality) (Kotler \& Scheff, 2007). Grisolia et al. (2010) added socio-economic variables. Among demographic criteria, Kotler and Scheff (1997), Grisolia et al. (2010), and others emphasized education and income variables as crucial ones. Since consumers' satisfaction is 
crucial to retaining existing customers and attracting new ones, several authors identified satisfaction with a cultural product as a key segmentation determinant (Oom do Valle et al., 2010; Jobst \& Boerner, 2011; and others).

Ngobo (2005) found that age is a significant moderator in a consumer's frequency of performing arts attendance. Hager and Kopczynski Winkler (2012) claimed that age is perhaps the most discussed demographic driver in the performing arts. Favaro and Frateschi (2007) came to the same conclusion in their study of Italian audiences (in this case, the effect was moderated by the type of performance attended). Willis et al. (2012) in their study proved that geographical distance negatively influenced the number of theatre visits. Most research on performing arts attendees centred on one or more components of social class, such as income, education, or occupation (Solomon et al., 2010). Andreasen (1987) concluded that more frequent attendees of classical performances tended to be of higher education or higher income, and that these attendees had been socialized to performing arts in childhood. Similarly, Masters et al (2001) proved education to be significant in predicting Australians' performing arts attendance. Falk and Falk (2011) compared EU countries and found that all the components of social class (income, education, and occupation) were a significant predictor of consumers' performing arts attendance.

Regarding audience segmentation, we have emphasized a few studies. Sargeant's (1997) research into British theatres has identified three segments, i.e. clusters of theatre visitors: nouveau sophisticates (youngest segment, high interest for arts in general) bluemooners (the least educated, lowest attendance rate, least demanding) and ageing socialites (oldest, most important motivation is the participation in social occasion).

Andreasen and Belk (1980) identified "culture patrons" and "socially-active" segments to be the most frequent theatre visitors. As a result of their favourable attitudes toward the arts, cultural patrons are highly involved in theatre because of their favourable attitudes toward the arts. They rely very little on television for entertainment or relaxation. The socially active are less frequent attendants than culture patrons, but they are aware of theatre offerings. They attend parties, eat out often, like reading, and spending quiet evenings at home. Andreasen later on (1992) developed a segmentation strategy based on stages in the performing arts adoption process, where he identified four key segments: disinterested and non-attendees' segment, trial and interest segment, positive evaluation segment, and adoption and confirmation segment.

McCarty and Jinnet (2001) have developed an Interest/ Attendance model of audience development and identified four segments: the participating segment, i.e. the existing market, the "inclined-to- participate" segment that has an interest but does not attend, the "no-inclination" segment consisting of those who attend but have no interest, and the "disinclined- to- participate" segment, with those who neither attend nor have interest.

Belgian arts sociologist Rudi Laermans segmented arts audiences using several different criteria, to classify the audience: professional involvement, experience with arts, and knowledge/competence. His inner circle is comprised of the "small, usually highly educated core audience." The second circle is called the "interested participants," who frequently make an appearance. The third is the "incidental visitors or participants.” They are more passers-by than participants (Laermans, 2002). Similarly, Roose (2008) distinguished three qualitatively different audience segments attending classical music concert: the " "inner circle," "outer circle,” or "passers-by’s,” and “interested participants,” who differ in their motivation to attend a cultural event (extrinsic vs. intrinsic motives) and the "socio-demographic profile.” The inner-circle members are older and very highly educated, they attend concerts out of an intrinsic and genuine interest for the particular musicians and/or orchestra performing and prefer innovative and unfamiliar pieces. Extrinsic motives for attendance, such as spending an evening out with friends or because they have been invited, are the most salient for the passers-by or the outer circle. They tend to be the youngest segment with the lowest educational capital, although this is a relative qualification: still, more than 60 per cent had obtained at least a bachelor's degree. Roose (2008) labelled the third segment, the interested participants, which is situated somewhere in between.

Guillon (2011) did a dual segmentation of theatre audiences based on different degrees and forms of loyalty. Her study confirmed that there was an individual propensity for loyalty that is based on both the inherent characteristics of attendees and contextual factors. Also, her research confirmed that different forms of loyalty do not always correspond to precisely the same logic of consumption and, therefore, are not always displayed concurrently. Chytkova et al. (2012) argued that traditionally- used demographic variables are context - insensitive and suggest the use of the benefit, i.e. motivations as a basis for segmentation. These benefits are identified as functional, symbolic, social, and emotional, and their study confirms differences in motivation as a significant predictor of theatre- visit frequency. Cavdar and Çobanoğlu (2018) have used clustering analysis with the same approach, benefit segmentation, which investigates benefits sought in theatre visit. They have identified four characteristic segments: enthusiasts, utilitarians, hedonistics, and socializers groups. 


\section{Research}

In the performing arts literature, three groups of variables are used for audience segmentation, that is, geographic (e.g., region, distance from the venue), demographic (e.g., age, income), and psychographics (e.g., lifestyle, personality), and this is the approach that was taken in this study. A self-completion questionnaire was developed upon analysis of previous studies and distributed to the population in the area of about $50 \mathrm{~km}$ around Osijek. The questionnaire was developed with a goal to evaluate respondents' attendance at the Croatian National Theatre in Osijek (in further text HNK Osijek) and its relation to the socio-economic characteristics of respondents.

\section{Methodology}

The research was conducted on a convenient sample using an in-person method in two different intervals: in the first interval, research was conducted on young respondents (18-35), and in the second interval, research was conducted on adult respondents (age 35+). Altogether 1315 participants took part in the research. The information obtained was analysed using the statistical software package SPSS version 21.0. The statistical technique of Two-Step cluster analysis was used. Table 1 depicts the detailed sample description.

Table 1. Sample description

\begin{tabular}{|c|c|c|c|c|c|}
\hline & & \multicolumn{2}{|c|}{ Young respondents } & \multicolumn{2}{|c|}{ Adult respondents } \\
\hline & & $\mathrm{N}$ & $\%$ & $\mathrm{~N}$ & $\%$ \\
\hline \multirow{2}{*}{ Gender } & Male & 355 & 40.5 & 206 & 47 \\
\hline & Female & 518 & 59.1 & 232 & 53 \\
\hline \multirow{4}{*}{ Age $^{*}$} & $35-45$ & 335 & 38.2 & 222 & 50.7 \\
\hline & $46-55$ & 306 & 34.9 & 135 & 30.8 \\
\hline & $56-65$ & 141 & 16.1 & 58 & 13.7 \\
\hline & $66-78$ & 88 & 10 & 23 & 4.8 \\
\hline \multirow{3}{*}{ Place of residence } & Osijek & 569 & 65 & 304 & 69.4 \\
\hline & Other urban areas & 34 & 3.9 & 84 & 19.2 \\
\hline & Rural area & 142 & 16.2 & 50 & 11.4 \\
\hline \multirow{4}{*}{$\begin{array}{l}\text { Completed level of } \\
\text { education }\end{array}$} & Primary school & 10 & 1.1 & 20 & 4.6 \\
\hline & Secondary school & 573 & 65.4 & 196 & 44.7 \\
\hline & College/university & 268 & 30.6 & 195 & 44.5 \\
\hline & Postgraduate & 22 & 2.5 & 27 & 6.2 \\
\hline \multirow{3}{*}{ Employment status } & Employed & 214 & 24.4 & 306 & 69.9 \\
\hline & Unemployed & 137 & 15.6 & 73 & 16.7 \\
\hline & Retired & 523 & 59.7 & 59 & 13.5 \\
\hline \multirow{4}{*}{$\begin{array}{l}\text { Average monthly } \\
\text { household income }\end{array}$} & Up to $400 €$ & 153 & 17.5 & 64 & 14.6 \\
\hline & $401-800 €$ & 319 & 36.4 & 190 & 43.4 \\
\hline & $801-1200 €$ & 218 & 24.9 & 121 & 27.6 \\
\hline & Over $1200 €$ & 177 & 20.2 & 63 & 14.4 \\
\hline \multirow{2}{*}{$\begin{array}{l}\text { Social networks } \\
\text { active }\end{array}$} & Yes & 783 & 89.4 & 262 & 59.8 \\
\hline & No & 83 & 9.5 & 176 & 40.2 \\
\hline
\end{tabular}

*Age intervals in the first column are related to young respondents' age groups, and age intervals in the second column are related to adult respondents' age groups 
Table 2. Cluster description of young audience according to their theatre attendance (demographic and geographic characteristics)

Cluster 1

Cluster description
Cluster 2

Young theatre acquaintance

$(\mathrm{N}=394)$
Cluster 3

Young theatre strangers

$(\mathrm{N}=53)$

$(\mathrm{N}=427)$

\section{Demographic characteristics}

\begin{tabular}{|c|c|c|c|}
\hline Age & & $\%$ & \\
\hline $18-21$ & 25 & 35.5 & 43.2 \\
\hline $22-25$ & 36.5 & 37 & 33.3 \\
\hline $26-30$ & 23.1 & 15.3 & 16.3 \\
\hline $30-35$ & 15.4 & 12.2 & 7.3 \\
\hline Gender & & $\%$ & \\
\hline Male & 30.2 & 35.6 & 46.6 \\
\hline Female & 69.8 & 64.4 & 53.4 \\
\hline Working status & & $\%$ & \\
\hline Employed & 35.8 & 28.5 & 19.2 \\
\hline Unemployed & 7.5 & 13.7 & 18.5 \\
\hline Student & 56.6 & 57.8 & 62.2 \\
\hline Marital status & & $\%$ & \\
\hline Married & 28.3 & 17.8 & 14.2 \\
\hline Single & 71.7 & 82.2 & 85.8 \\
\hline Education & & $\%$ & \\
\hline Elementary school & 1.9 & 0.8 & 1.4 \\
\hline High school & 45.3 & 61.1 & 72.5 \\
\hline Faculty & 47.2 & 35.1 & 24.5 \\
\hline Masters or doctorate & 5.7 & 3.1 & 1.6 \\
\hline Average household income & & $\%$ & \\
\hline Less than $400 €$ & 11.3 & 15.2 & 20.6 \\
\hline $400-800 €$ & 34 & 41.1 & 33.1 \\
\hline $801-1200 €$ & 24.5 & 24.9 & 25.5 \\
\hline More than $1200 €$ & 30.2 & 18.8 & 20.8 \\
\hline \multicolumn{4}{|c|}{ Geographic characteristics } \\
\hline Place of residence & & $\%$ & \\
\hline Osijek & 84.9 & 72.8 & 56.5 \\
\hline Other town/city & 3.8 & 11.3 & 26 \\
\hline Village & 11.3 & 15.9 & 17.5 \\
\hline
\end{tabular}

Clusters were named according to theatre attendance. Frequent young attendants were called young theatre friends, occasional young attendants were called young theatre acquaintances and young non-attendants were called young strangers. 
Table 3. Cluster description of young audience according to their theatre attendance (psychographic characteristics)

\begin{tabular}{|c|c|c|c|}
\hline Cluster description & $\begin{array}{l}\text { Cluster } 1 \\
\text { Young theatre friend }(\mathrm{N}=53)\end{array}$ & $\begin{array}{c}\text { Cluster } 2 \\
\text { Young theatre acquaintance } \\
(\mathrm{N}=394)\end{array}$ & $\begin{array}{c}\text { Cluster } 3 \\
\text { Young theatre stranger } \\
(\mathrm{N}=427)\end{array}$ \\
\hline \multicolumn{4}{|c|}{ Psychographic characteristics } \\
\hline $\begin{array}{l}\text { Information gathering } \\
\text { about theatre }\end{array}$ & & $\%$ & \\
\hline \multicolumn{4}{|l|}{ Web page } \\
\hline Often & 44 & 20.6 & 9.6 \\
\hline Sometimes & 48 & 44.5 & 32.4 \\
\hline Never & 8 & 34.8 & 67.6 \\
\hline \multicolumn{4}{|l|}{ Social networks } \\
\hline Often & 31.3 & 16.4 & 8.6 \\
\hline Sometimes & 41.7 & 41.6 & 23.1 \\
\hline Never & 27.1 & 41.9 & 68.3 \\
\hline \multicolumn{4}{|l|}{ Print media } \\
\hline Often & 40.8 & 17.9 & 7.9 \\
\hline Sometimes & 34.7 & 45 & 27.2 \\
\hline Never & 24.5 & 37.1 & 65 \\
\hline \multicolumn{4}{|l|}{ Friends' recommendation } \\
\hline Often & 53.8 & 32.6 & 10.2 \\
\hline Sometimes & 40.4 & 49.6 & 36.5 \\
\hline Never & 5.8 & 17.8 & 53.3 \\
\hline \multicolumn{4}{|l|}{ Theatre posters } \\
\hline Often & 43.1 & 33.1 & 16.5 \\
\hline Sometimes & 45.1 & 48.1 & 37.1 \\
\hline Never & 11.8 & 18.8 & 46.4 \\
\hline Program preferences & & Mean (max. 5) & \\
\hline Drama & 4.02 & 3.72 & 3.23 \\
\hline Comedy & 4.4 & 4.56 & 4.5 \\
\hline Opera & 2.92 & 2.54 & 2.21 \\
\hline Spending leisure time & & Most frequent category & \\
\hline Doing sports & Daily (40\%) & Weekly (39.4\%) & Weekly (33.3\%) \\
\hline Reading books & Daily (31.4\%) & Never (23.2\%) & Never (25.6\%) \\
\hline Watching TV & Daily (49\%) & Daily (53.3\%) & Daily (59\%) \\
\hline Surfing the internet & Daily (75.5\%) & Daily (87.8\%) & Daily (89.4\%) \\
\hline Reading newspapers & Weekly (31.3\%) & Daily (43.1\%) & Daily (37.2\%) \\
\hline Reading magazines & $2-3$ times in a month (25\%) & Weekly (35.5\%) & Weekly (29\%) \\
\hline Going to the cinema & Never (32.6\%) & Never (47.9\%) & Never (50.3\%) \\
\hline Going to parties & Monthly (27.1\%) & Weekly (32.1\%) & Weekly (36.9\%) \\
\hline Going to modern music concerts & Never (34.8\%) & Never (52.8\%) & Never (49.6\%) \\
\hline $\begin{array}{l}\text { Going to the theatre, classical music } \\
\text { concerts, exhibitions, etc. }\end{array}$ & $\begin{array}{c}2-3 \text { times a month (33.3\%) } \\
\text { Monthly }(33.3 \%)\end{array}$ & $\begin{array}{l}\text { Never (55.5\%) } \\
\text { Monthly (21.6\%) }\end{array}$ & Never (49.1\%) \\
\hline
\end{tabular}


Table 4. ANOVA test results - young audience

\begin{tabular}{lccc} 
& $\begin{array}{c}\text { Young theatre friend } \\
(\text { Mean })\end{array}$ & $\begin{array}{c}\text { Young theatre acquaintance } \\
(\text { Mean })\end{array}$ & $\begin{array}{c}\text { Young theatre stranger } \\
(\text { Mean })\end{array}$ \\
\hline $\begin{array}{l}\text { Cultural products } \\
\text { consumption }\end{array}$ & $2.4706^{*}$ & $1.6000(p=0.000)$ & $1.7160(p=0.000)$ \\
\hline Comedy preference & 4.4091 & 4.5598 & 4.4972 \\
\hline Opera preference & $2.9268^{*}$ & $2.5389(p=0.004)$ & $2.2110(p=0.003)$ \\
\hline Drama preference & $4.0233^{*}$ & $3.7235(p=0.000)$ & $3.2330(p=0.000)$ \\
\hline
\end{tabular}

*Statistically significant difference in relation to other two segments (level of statistical significance for each of two segments is shown the brackets)

\section{Findings and Discussion}

\section{Cluster analysis - young audience}

Cluster analysis was the most appropriate statistical technique for market segmentation. It can provide description of different clusters that can be turned into market segments. Two- Step cluster analysis was used in this research because it is designed to efficiently handle large datasets, is capable of handling both continuous and categorical variables, and has features to aid in determining the optimal number of clusters (Landau \& Everitt, 2004). This research has used only one criterion for developing and describing market segments: classical theatre attendance frequency. The variable used for clustering is categorical, and the possible categories were: a) subscriber, b) frequent attendance (at least once in two months), c) occasional attendance (a couple of times a year) and d) non-attendance (never). The results of the analysis on the young audience identified 3 clusters where subscribers and those who often attend classical theatre were placed in the first cluster that was named young theatre friend; occasional attendees were placed in a second cluster named young theatre acquaintance, and non-attendants were placed in the third cluster named young theatre strangers. The largest cluster was young theatre strangers with 427 respondents (49\%), the cluster with young theatre acquaintances had 394 respondents (45\%) and the smallest cluster called young theatre friends had only 53 respondents (6\%). The clusters were evaluated by their demographic and geographic characteristics (Table 2) and their psychographics characteristics (Table 3).

To identify some statistically significant key differences between the three identified segments, an ANOVA test was performed. The test aimed to see if there were statistically significant differences between three young audience segments according to their general cultural product consumption (going to the theatre, classical music concerts, exhibitions, etc.) and their preferences when it comes to theatre program (comedy, drama, opera). Table 4 depicts the results of the ANOVA test.
Results have shown that the first cluster (young theatre friend) consumed cultural products significantly more than the other two segments. Also, when it comes to the content of the program, this segment prefers drama and opera significantly more compared to the other two segments.

Based on tables 2, 3, and 4, it is possible to make young segment profiles.

Young theatre friends are mostly women, from age 22 to age 25 and single. They are mostly highly educated (or students) with higher household income and live in the city where the theatre is located. They most often get informed about theatre through friends' recommendations, theatre web pages, and theatre posters. When it comes to the theatre program, they preferred comedies and drama in a theatre program, and significantly more opera and drama than did the other two segments. They mainly spend their leisure time doing sports, reading books, watching TV, and surfing the internet daily. They read newspapers once a week and magazines 2-3 times a month. They also attend theatre, classical music concerts and exhibitions 2-3 times a month, and parties once a month. They hardly ever attend the cinema or modern music concerts.

Young theatre acquaintances are mostly women, aged 22 to 25 and single. They are mostly highly educated (or students) with an average household income from $400-800$ euros and live in the city where a theatre is located. They usually get information about theatre through theatre posters and friends' recommendations. When it comes to the theatre program, they strongly prefer comedies. They usually spend their leisure time watching TV, surfing the internet, and reading newspapers daily. At least once a week they play sports, read magazines and attend parties. They rarely attend cinema, modern music concerts or theatre, classical music concerts, exhibitions, etc.

Young theatre strangers are approximately equally men and women, mostly in ages $18-21$ and single. Their level of education is mostly high school, their average income is 
400 - 800 euros, and they mostly live in the city where theatre is located even though a significantly higher percentage of this segment compared to the two previous groups lives in some other town or city. They usually do not seek information about theatre but would be interested in watching comedies. They spend their leisure time watching TV, surfing the internet, and reading newspapers on daily basis. At least once a week, they play sports, read magazines, and attend parties. They rarely consume other cultural products: books, cinema, modern music concerts and theatre, classical music concerts, exhibitions, etc.

Table 5. Cluster description of adult audience according to their theatre attendance (demographic and geographic characteristics)

\begin{tabular}{|c|c|c|c|}
\hline Cluster description & $\begin{array}{l}\text { Cluster } 1 \\
\text { Adult theatre friend } \\
(\mathrm{N}=29)\end{array}$ & $\begin{array}{c}\text { Cluster } 2 \\
\text { Adult theatre acquaintance } \\
(\mathrm{N}=238)\end{array}$ & $\begin{array}{c}\text { Cluster } 3 \\
\text { Adult theatre stranger } \\
(\mathrm{N}=170)\end{array}$ \\
\hline \multicolumn{4}{|c|}{ Demographic characteristics } \\
\hline Age & & $\%$ & \\
\hline $35-43$ & 48.3 & 52.5 & 45.3 \\
\hline $44-51$ & 20.7 & 23.9 & 20.6 \\
\hline $52-59$ & 13.8 & 18.1 & 15.9 \\
\hline $60+$ & 17.2 & 5.5 & 18.2 \\
\hline Gender & & $\%$ & \\
\hline Male & 39.3 & 41.6 & 56.5 \\
\hline Female & 60.7 & 58.4 & 43.5 \\
\hline Working status & & $\%$ & \\
\hline Employed & 79.3 & 78.6 & 56.5 \\
\hline Unemployed & 6.9 & 14.3 & 21.8 \\
\hline Retired & 13.8 & 7.1 & 21.8 \\
\hline Marital status & & $\%$ & \\
\hline Married & 65.5 & 80.3 & 74.6 \\
\hline Single & 34.5 & 19.7 & 25.4 \\
\hline Education & & $\%$ & \\
\hline Elementary school & 0 & 1.7 & 9.4 \\
\hline High school & 31 & 38.2 & 55.9 \\
\hline College/university & 58.6 & 51.3 & 32.9 \\
\hline Masters or doctorate & 10.3 & 8.8 & 1.8 \\
\hline Average household income & & $\%$ & \\
\hline Less than $400 €$ & 6.9 & 8.4 & 24.7 \\
\hline $400-800 €$ & 34.5 & 44.1 & 43.5 \\
\hline $801-1200 €$ & 41.4 & 31.1 & 20.6 \\
\hline More than $1200 €$ & 17.2 & 16.4 & 11.2 \\
\hline \multicolumn{4}{|c|}{ Geographic characteristics } \\
\hline Place of residence & & $\%$ & \\
\hline Osijek & 74.1 & 70.2 & 74.5 \\
\hline Other town/city & 18.5 & 19.3 & 13.9 \\
\hline Village & 7.4 & 10.5 & 11.5 \\
\hline
\end{tabular}


Table 6. Cluster description of adult audience according to their theatre attendance (psychographic characteristics)

\begin{tabular}{|c|c|c|c|}
\hline Cluster description & $\begin{array}{l}\text { Cluster } 1 \\
\text { Adult theatre friend } \\
(\mathrm{N}=29)\end{array}$ & $\begin{array}{l}\text { Cluster } 2 \\
\text { Adult theatre acquaintance } \\
(\mathrm{N}=238)\end{array}$ & $\begin{array}{c}\text { Cluster } 3 \\
\text { Adult theatre stranger } \\
(\mathrm{N}=170)\end{array}$ \\
\hline \multicolumn{4}{|c|}{ Psychographic characteristics } \\
\hline Information gathering about theatre & & $\%$ & \\
\hline \multicolumn{4}{|l|}{ Web page } \\
\hline Often & 53.6 & 19.9 & 6.9 \\
\hline Sometimes & 21.4 & 47.5 & 13.8 \\
\hline Never & 25 & 32.6 & 79.4 \\
\hline \multicolumn{4}{|l|}{ Social networks } \\
\hline Often & 51.9 & 16.5 & 6.9 \\
\hline Sometimes & 25.9 & 38 & 10 \\
\hline Never & 22.2 & 45.6 & 83.1 \\
\hline \multicolumn{4}{|l|}{ Printed media } \\
\hline Often & 35.7 & 27.7 & 15.8 \\
\hline Sometimes & 25 & 42.9 & 29.1 \\
\hline Never & 39.3 & 29.4 & 56.3 \\
\hline \multicolumn{4}{|l|}{ Friends' recommendation } \\
\hline Often & 28.6 & 39.9 & 26.3 \\
\hline Sometimes & 53.6 & 45 & 17.5 \\
\hline Never & 17.9 & 15.1 & 56.3 \\
\hline \multicolumn{4}{|l|}{ Theatre posters } \\
\hline Often & 63 & 48.1 & 20.5 \\
\hline Sometimes & 29.6 & 36.2 & 25 \\
\hline Never & 7.6 & 15.7 & 54.5 \\
\hline Program preferences & & Mean (max. 5) & \\
\hline Drama & 4.11 & 3.89 & 3.47 \\
\hline Comedy & 4.32 & 4.22 & 4.01 \\
\hline Opera & 3.11 & 2.77 & 2.01 \\
\hline Spending leisure time & & Most frequent category & \\
\hline Doing sports & Weekly (41.4\%) & Weekly (29.8\%) & Monthly (31.2\%) \\
\hline Reading books & Monthly (37.9\%) & Monthly (33.6\%) & Monthly (37.9\%) \\
\hline Watching TV & Daily (69\%) & Daily (64.7\%) & Daily (67.1\%) \\
\hline Surfing the internet & Daily (75.9\%) & Daily (71.4) & Daily (52.4\%) \\
\hline Reading newspapers & Daily (65.5\%) & Daily (39.5\%) & Daily (37.6\%) \\
\hline Reading magazines & $\begin{array}{c}\text { Monthly (24.1\%) } \\
\text { Never (24.1\%) }\end{array}$ & Monthly (28.5\%) & Never (29\%) \\
\hline Attending cinema & Monthly (51.7\%) & Monthly (67.3\%) & Never (41.2\%) \\
\hline Attending parties & Never (62.1\%) & Monthly (37.8\%) & Never (49.4\%) \\
\hline Attending modern music concerts & Monthly (51.7\%) & Monthly (51.3\%) & Never $(66.9 \%)$ \\
\hline $\begin{array}{l}\text { Attending theatre, classical music } \\
\text { concerts, exhibitions, etc. }\end{array}$ & Monthly (48.3\%) & Monthly (65.4\%) & Never (66.9\%) \\
\hline
\end{tabular}


Table 7. ANOVA test results - adult audience

\begin{tabular}{lccc} 
& $\begin{array}{c}\text { Adult theatre friend } \\
(\text { Mean })\end{array}$ & $\begin{array}{c}\text { Adult theatre acquaintance } \\
(\text { Mean })\end{array}$ & $\begin{array}{c}\text { Adult theatre stranger } \\
(\text { Mean })\end{array}$ \\
\hline Cultural product consumption & $3.3571^{*}$ & $2.3935(p=0.000)$ & $1.4403(p=0.000)$ \\
\hline Comedy preference & 4.32 & 4.22 & 4.01 \\
\hline Opera preference & $3.11^{*}$ & $2.77(p=0.000)$ & $2.01(p=0.000)$ \\
\hline Drama preference & $4.11^{*}$ & $3.89(p=0.003)$ & $3.47(p=0.030)$ \\
\hline
\end{tabular}

*Statistically significant difference in relation to other two segments (level of statistical significance for each of two segments is shown the brackets)

\section{Cluster analysis - adult audience}

In common with the young audience, only one criterion for developing and describing adult market segments was used: classical theatre attendance frequency. The same variable was used for clustering: How often do you visit classical theatre: a) subscriber, b) often attendance (at least once in two months), c) occasional attendance (two or more times a year), and d) non-attendance (never). The results of the analysis on the adult audience also identified three clusters. Subscribers and those who often attend classical theatre were placed in the first cluster, titled the adult theatre friends; occasional attendees were placed in a second cluster named adult theatre acquaintances; and non-attendees were placed in the third cluster, named adult theatre strangers. The largest cluster was the one called adult theatre acquaintances with 238 respondents (54\%), the cluster called adult theatre strangers had 170 respondents (39\%), and the smallest cluster called adult theatre friends had only 29 respondents $(6,6 \%)$. The clusters were evaluated by their demographic and geographic characteristics (Table 4) and their psychographics characteristics (Table 5).

As with the young audience, the ANOVA test was performed for the adult audience. The aim of the test was to see if there are statistically significant differences between three adult audience segments according to their general cultural product consumption (going to the theatre, classical music concerts, exhibitions, etc.) and their preferences when it comes to the type of theatre program (comedy, drama, opera). Table 7 depicts the results of the ANOVA test.

The results were the same as with the young audience: cultural product consumption was significantly higher in adult theatre friends than in the other two segments. Also, this segment preferred opera and drama more than the other two segments.

Based on tables 5, 6, and 7, it is possible to identify adult segment profiles. These segments were named according to theatre attendance. Frequent adult attendants are called adult theatre friends, occasional adult attendees are called adult theatre acquaintances, and adult non-attendees are called adult strangers.

Adult theatre friends are mostly women, aged 35 to 43, employed and married. They are mostly highly educated, with an average monthly income from 801 to 1200 euros, and mostly live in the city where the theatre is located. When it comes to information gathering about theatre, they mostly receive information through theatre posters, theatre web pages, and social networks. In general, they prefer comedy and drama in theatre programs, but significantly more opera and drama than the other two segments. When it comes to spending their free time, they mostly watch $\mathrm{TV}$, surf the internet and read newspapers on daily basis; at least once a week they play sports, and once a month they read books and magazines, attend cinema, listen to modern music concerts, theatre, classical concerts and exhibitions. They rarely go to parties.

Adult theatre acquaintances are mostly women, from age 35 to 43, employed, and married. They are mostly highly educated with an average monthly income from 400 to 800 euros and live in the city where the theatre is located. They usually get information about theatre through theatre posters and friends' recommendations. They strongly prefer comedies. When it comes to their leisure time, they watch $\mathrm{TV}$, surf the internet, and read newspapers daily. At least once a week, they play sports and, at least once a month, they read books, magazines, attend cinema, parties as well as theatre, classical music concerts, exhibitions, etc.

Adult theatre strangers are mostly men, aged 35 to 43, employed, and married. Their level of education was mostly high school, their average monthly income was from 400 to 800 euros, and they mostly live in the city where a theatre is located. They rarely seek information about theatre, and would slightly prefer comedies when it comes to the theatre program. For leisure, they watch TV, surf the internet, and read newspapers daily. Once a month, they may 
play sports and read books, but they rarely read magazines, attend cinema, parties, modern music concerts or the theatre, classical music concerts, exhibitions, etc.

Furthermore, the study compared the two age groups and their identified segments. We found no significant differences between the age groups of the same segments in their residence, method of information gathering about theatre, and theatre program preferences. However, there were differences in the size of the segments. The largest segment in the young age group was the non-attendees, i.e. theatre strangers (49\%), and in the adult group, the largest segment were the occasional visitors, i.e. theatre acquaintances (54\%). Among both age groups attendees, i.e. theatre friends were the smallest segments, with only $6 \%$ in the young age group and $6.6 \%$ in the $35+$ age group. For both age groups, important factors for theatre attendance were similar:

1. Income, in which higher income was related to more frequent theatre attendance, confirming the previous findings of Kotler and Scheff (1997) and Grisolia et al. (2010);

2. Gender, in which females were significantly more frequent theatre attendees in both age groups. This contrasted with the findings of Borongovi (2004), who found that females were more likely than males to attend, and to do so as occasional visitors. Further when males participated, they were more likely than females to be frequent attendees. Also, Hager and Kopczynski Winkler (2012) study found no significant differences regarding gender and age but did find socio-economic status as an important factor in attracting theatre audiences. In our case study, the theatre was more of a "female thing", in both age groups and at both levels of attendance.

3. Level of education, where higher levels of education were positively related to more frequent theatre attendance. This had also been identified as crucial by Kotler and Scheff (1997) and Grisolia et al. (2010), and

4. Lifestyle, where an overall higher consumption of cultural products (books, exhibitions, music concerts) was positively related to more frequent theatre attendance.

A recent study (Leko Šimić \& Pap, 2019) on theatre visitors' satisfaction has also identified differences between the two age groups and visiting frequency. The occasional visitors' segment was the most critical, and the discrepancies between the expectations and experiences were highest, in general. Satisfaction with a theatre/cultural product was also emphasized as a segmentation criterion in several other studies (Oom do Valle, Mendes, \& Guerreiro, 2010; Jobst \& Boerner, 2011, among others).

\section{Conclusion}

The study aimed to get an insight into the classic- theatre market segmentation. The findings of the research contribute to theatre segmentation theory and classical theatre marketing practice. Segments identified in this study offered insights into classical theatre segments according to their attendance, frequency, and age.

Since there is limited research on market segmentation on cultural products and events in Croatia, this study contributed to building knowledge about classic theatre audiences and for marketing strategy creation for different theatre segments, which is increasingly important in the growing competition among cultural products.

In two age groups (young, i.e. age 18-35 and adult, i.e. age $35+$ ), three segments were identified: theatre friends, theatre acquaintances, and theatre strangers. Besides the compliance with studies that identify socio-demographic and economic characteristics of more frequent theatre visitors (female, higher income, higher education), this study confirmed that theatre attendance is a significant symbol of a lifestyle and is strongly related to the consumption of other cultural products.

Our research results also emphasized the differences in classic theatre audiences, which require continuous market segmentation to ensure timely recognition of consumer trends and changes in their preferences. Theatre management can then adapt and implement adequate marketing initiatives and strategies. Noting that the classic theatre audience is aging, the focus of marketing strategies should be put onto younger audiences, whose cultural profile can be influenced. Since the "young theatre strangers” segment was generally not interested in cultural products consumption, our suggestion is to focus on the "young theatre acquaintances" segment. In this context, the adaptation of theatre programs in terms of addressing this young population interests in cultural products could include more "easy products," based on edutainment, special performances for young audiences (eg. late-night shows, stand-up comedies), pre- or post- performance events (eg. meeting with actors or, discussions on performances) that engages the young audiences. Additionally, special price packages for young audiences can be adopted.

The major limitations of this study are the facts that, although the sample was large and representative, it was a convenient one, and the research was performed in only one classic theatre - HNK Osijek. Therefore, the results may not be representative of other classic theatres in Croatia, or in other countries. Also, some other segmentation criteria might have been included into the analysis, especially recent concepts of sought benefits or satisfaction. These are the points on which the further research should be focused. 


\section{References}

Andreasen, A. R. (1992). Expanding the Audience for the Performing Arts. Cabin John, MD: Seven Locks Press.

Andreasen, A. R., \& Belk, R. W. (1980). Predictors of attendance at the performing arts. Journal of Consumer Research, 7(2), $112-120$. https://doi.org/10.1086/208800

Andreasen, A. R. (1987). Expanding the Audience for the Performing Arts. Washington, DC: National Endowment for the Arts, Research Div. Retrieved from https://files.eric.ed.gov/fulltext/ED289804.pdf

Ashton, D. \& Gowland - Pryde, R. (2019). Arts audience segmentation: Data, profiles, segments and biographies. Cultural Trends, 28(23), 146-161. https://doi.org/10.1080/09548963.2019.1617938

Bernstein, J. S. (2007). Arts Marketing Insights: The Dynamics of Building and Retaining Performing Arts Audiences. San Francisco: John Wiley \& Sons.

Buljubašić, I., Mijoč, J., \& Jobst, I. (2020): The effectiveness of unconventional marketing in theatres: Top management theatre perspective, In: M. Leko Šimić \& B. Crnković (eds.) Proceedings of $9^{\text {th }}$ RED international scientific symposium (130-142). Osijek: Faculty of Economics

Carson, C. (2004). Turning conventional theatre inside out: Democratising the audience relationship. In: G. Carver, \& C. Beardon (eds.) New Visions In Performance, (167-180). Oxford: Routledge

Cavdar, N., \& Çobanoğlu, E. A. (2018). Segmentation study of theater audiences based on benefits sought. International Journal of Liberal Arts and Social Science 5(8):57-79.

Colbert, F. (1994). Marketing culture and the arts. Montreal and Paris: Morin

Chytkova, Z, Černa,J. \& Karliček, M. (2012). Segmenting the performing arts markets: The case of Czech National Theatre attenders' motivations. Journal of Competitiveness 4(3), 92-104. https://doi.org/10.7441/joc.2012.03.07

da Costa Mendes, J., Oom do Valle, P., Guerreiro, M. M., \& Silva, J. A. (2010). The tourist experience: Exploring the relationship between tourist satisfaction and destination loyalty. Turizam, 58(2), 111-126.

Conway, T., \& Whitelock, J. (2007). Relationship marketing in the subsidised arts: The key to a strategic marketing focus? European Journal of Marketing, 41(1/2), 199-222. https://doi.org/10.1108/03090560710718184

Falk, M., \& Falk, R. (2011). An ordered probit model of live performance attendance for 24 EU Countries. Austrian Institute of Economic Research (WIFO), 1-25.

Favaro, D., \& Frateschi, C. (2007). A discrete choice model of consumption of cultural goods: The case of music. Journal of Cultural Economics, 31(3), 205-234. https://doi.org/10.1007/s10824-007-9043-x

Grisolía, J. M., Willis, K., Wymer, C., \& Law, A. (2010). Social engagement and regional theatre: Patterns of theatre attendance. Cultural Trends, 19(3), 225-244. https://doi.org/10.1080/09548963.2010.495277

Guillon, O. (2011). Loyalty behaviours and segmentation of performing arts audiences: The case of Théâtre de l'Athénée in Paris. International Journal of Arts Management, 14(1), 32.

Hager, M. A., \& Kopczynski Winkler, M. (2012). Motivational and demographic factors for performing arts attendance across place and form. Nonprofit and Voluntary Sector Quarterly, 41(3), 474-496. https://doi.org/10.1177/0899764011411095

Heilbrun, J., \& Gray, C. M. (2001). The Economics of Art and Culture. Cambridge, UK: Cambridge University Press. https://doi. org/10.1017/CBO9780511754135

Jobst, J., \& Boerner, S. (2011). Understanding customer satisfaction in opera: First steps toward a model. International Journal of Nonprofit and Voluntary Sector Marketing, 16(1), 50-69. https://doi.org/10.1002/nvsm.394

Kolb, B. M. (2001). The decline of the subscriber base: A study of the Philharmonia Orchestra audience. International Journal of Arts Management, 3(2), 51-59.

Kolhede, E., \& Gomez-Arias, J. (2016). Segmentation of infrequent performing arts consumers. Arts and the Market, 6(1), 88-110. https://doi.org/10.1108/AAM-04-2014-0015

Kotler, Ph., \& Scheff, J. (1997). Standing Room Only: Strategies for Marketing the Performing Arts. Boston, MA: Harvard Business School Press.

Laermans, R. (2002). Het Vlaams Cultureel Regiem. Centrum voor Cultuursociologie (CCS): Leuven.

Landau, S., \& Everitt, B. S. (2003). A Handbook of Statistical Analyses using SPSS. Boca Raton London New York Washington, D.C: Chapman \& Hall/CRC. https://doi.org/10.1201/9780203009765

Le, H., Jones, B., Williams, T., \& Dolnicar, S. (2016). Communicating to culture audiences. Marketing Intelligence \& Planning, 34(4), 462-485. https://doi.org/10.1108/MIP-05-2015-0102

Leko Šimić, M., Pap,A.(2019). Theatre Marketing - Analysis of Customers' Satisfaction. Marketing \& Menedzsment 53(4), 39-51https:// doi.org/10.15170/MM.2019.53.04.04

Leko Šimić, M. \& Pap, A. (2020). Insight Into Adult Classic Theatre Audiences' Perceptions and Behaviour. Global Economics Science, 1(1), 12-22. https://doi.org/10.37256/ges.112020146.12-22

Masters, T., Russell, R., \& Brooks, R. (2011). The demand for creative arts in regional Victoria, Australia. Applied Economics, 43(5), 619-629. https://doi.org/10.1080/00036840802584976 
McCarthy, K. F., \& Jinnett, K. J. (2001). A new framework for building participation in the arts. Santa Monica, California, USA: Rand Corporation.

Ngobo, P. V. (2005). Drivers of upward and downward migration: An empirical investigation among theatregoers. International Journal of Research in Marketing, 22(2), 183-201. https://doi.org/10.1016/j.ijresmar.2004.07.002

Nielsen, R. P., McQueen, C. \& Nielsen, A. B. (1974). Performing arts audience segments. Journal of the Academy of Marketing Science, 2(4), 602-609. https://doi.org/10.1007/BF02729453

Obaidalahe, Z., \& Steils, N. (2018). Motivation trajectory of attending performing arts: the role of knowledge. Arts and the Market, 8(1), 5-18. https://doi.org/10.1108/AAM-02-2017-0001

Oom do Valle, P., Mendes, J. \& Guerreiro, M. (2010). Sustainable cultural events based on marketing segmentation: Case of Faro Capital of culture. Pasos, 8(3), 91-104. https://doi.org/10.25145/j.pasos.2010.08.037

Pap, A., Dlačić, J., \& Ham M. (2017). What makes the theatre audience return? The role of engagement in predicting future behaviour. Proceedings of 4th International Scientific Conference ToSEE-Tourism in Southern and Eastern Europe 2017: "Tourism and Creative Industries: Trends and Challenges" Opatija: University of Rijeka, Faculty of Tourism and Hospitality Management, 423-435.

Peterson, R. A., Hull, P. C., \& Kern, R. M. (2000). Age and arts participation: 1982-1997 (NEA Research Report No. 42). Washington, DC: National Endowment for the Arts.

Roose, H. (2008). Many-voiced or unisono? An inquiry into motives for attendance and aesthetic dispositions of the audience attending classical concerts. Acta Sociologica, 51(3), 237-253. https://doi.org/10.1177/0001699308094168

Sargeant, A. (1997). Marketing the arts: -A classification of UK theatre audiences. Journal of Nonprofit and Public Sector Marketing, 5(1), 45-62. https://doi.org/10.1300/J054v05n01_04

Solomon, M. R., Bamossy, G., Askegaard, S. \& Hogg, M. K. (2010). Consumer Behaviour: A European Perspective. London: Prentice-Hall.

Taylor, P., Owen, E., Bell, H., \& Withnall, S. (2001). Increasing young peopless attendances at the theatre: A case study in Sheffield, UK, Managing Leisure, 6(3), 141-153. https://doi.org/10.1080/13606710122792

Turrini, A., Soscia, I., \& Maulini, A. (2012). Web communication can help theaters attract and keep younger audiences. International Journal of Cultural Policy, 18(4), 474-485. https://doi.org/10.1080/10286632.2011.625420

Walmsley, B. A. (2011). Why people go to the theatre: A qualitative study of audience motivation. Journal of Customer Behaviour, 10 (4), 335-351. https://doi.org/10.1362/147539211X13210329822545

Willis, K. G., Snowball, J. D., Wymer, C., \& Grisolía, J. (2012). A count data travel cost model of theatre demand using aggregate theatre booking data. Journal of Cultural Economics, 36 (2), 91-112. https://doi.org/10.1007/s10824-011-9157-z

\section{Vpogled v tržne segmente klasičnega gledališča}

\section{Izvleček}

Segmentacija trženja je eden ključnih strateških elementov tržnega načrtovanja, ki pomaga prepoznati ključne skupine potrošnikov in njihove značilnosti ter omogoča prilagajanje tržne strategije različnim ciljnim potrošnikom. Namen tega prispevka je segmentirati klasično gledališko občinstvo na podlagi pogostosti njihovega obiska in prepoznati glavne socialno-demografske značilnosti vsakega segmenta. Na podlagi predhodnih študij je bil razvit vprašalnik za samoizpolnjevanje, ki je bil razdeljen prebivalstvu na območju približno 50 km okoli Osijeka. Raziskava je bila izvedena s priložnostnim vzorčenjem $z$ uporabo osebne metode $v$ dveh različnih intervalih: $v$ prvem intervalu je bila raziskava opravljena $z$ mladimi anketiranci (18-34), v drugem intervalu pa z odraslimi anketiranci (starimi 35+). V raziskavi je skupaj sodelovalo 1315 udeležencev. Uporabljene so bile statistične tehnike univariatne analize (frekvenčna porazdelitev in meritve centralne tendence), ANOVA in dvostopenjska grozdna analiza. Rezultati študije so opredelili šest klasičnih gledaliških segmentov: mladi prijatelji gledališča, mladi znanci gledališča, mladi gledališki tujci, odrasli prijatelji gledališča, odrasli znanci gledališča in odrasli gledališki tujci. Vsak segment je podrobno opisan glede na geografski položaj (oddaljenost od kraja), demografski vidik (starost, dohodek, zakonski stan, izobrazba, zaposlitev) in psihografske značilnosti (družbene dejavnosti, preživljanje prostega časa in zbiranje informacij o klasični gledališki ponudbi). Rezultati raziskave izpostavljajo razlike $v$ občinstvu klasičnega gledaličča, ki pozivajo k nenehni segmentaciji trga za zagotovitev pravočasnega prepoznavanja potrošniških trendov in sprememb preferenc. To bi vodstvu gledališča omogočilo prilagajanje in izvajanje ustreznih tržnih pobud ter strategij.

Ključne besede: klasično gledališče, segmentacija trženja, gledališko občinstvo 